\title{
New eco-friendly animal bone meal catalysts for preparation of chalcones and aza-Michael adducts
}

\author{
Yassine Riadi ${ }^{1,2+}$, Younes Abrouki ${ }^{3}$, Rachid Mamouni ${ }^{3}$, Mohammadine El Haddad ${ }^{4}$, Sylvain Routier ${ }^{2}$,
} Gérald Guillaumet ${ }^{2^{*}+}$ and Saïd Lazar ${ }^{1 * \dagger}$

\begin{abstract}
Two efficient reactions were successfully carried out using Animal Bone Meal (ABM) and potassium fluoride or sodium nitrate doped ABMs as new heterogeneous catalysts under very mild conditions. After preparation and characterization of the catalysts, we first report their use in a simple and convenient synthesis of various chalcones by Claisen-Schmidt condensation and then in an aza-Michael addition involving several synthesized chalcones with aromatic amines. All the reactions were carried out at room temperature in methanol; the chalcone synthesis was also achieved in water environment under microwave irradiation. Doping ABM enhances the rate and yield at each reaction. Catalytic activities are discussed and the ability to re-use the ABM is demonstrated.
\end{abstract}

Results: For Claisen-Schmidt the use of ABM alone, yields never exceeded 17\%. In each entry, $\mathrm{KF} / \mathrm{ABM}$ and $\mathrm{NaNO}_{3} /$ ABM (79-97\%) gave higher yields than using ABM alone under thermic condition. Also the reaction proceeded under microwave irradiation in good yields (72-94\% for KF/ABM and $81-97 \%$ for $\mathrm{NaNO}_{3} / \mathrm{ABM}$ ) and high purity. For aza-Michael addition the use of $\mathrm{ABM}$ doped with $\mathrm{KF}$ or $\mathrm{NaNO}_{3}$ increased the catalytic activity remarkably. The very high yields could be noted (84-95\% for KF/ABM and $81-94 \%$ for $\mathrm{NaNO}_{3} / \mathrm{ABM}$ ).

Conclusion: The present method is an efficient and selective procedure for the synthesis of chalcones an azaMichael adducts. The ABM and doped ABMs are a new, inexpensive and attractive solid supports which can contribute to the development of catalytic processes and reduced environmental problems.

\section{Background}

Heterogeneous catalytic reactions are interesting due to their well-documented advantages over homogeneous catalytic systems [1-3]. Animal Bone Meal (ABM) has emerged as an ideal basic heterogeneous catalyst as it is easily available in nature. The positive features of ABM also include high stability, ease of handling and regeneration, nontoxicity and the absence of other environmental hazards.

Our group has recently developed the preparation and use of Animal Bone Meal as a natural catalyst for C-S bond formation by thia-Michael addition [4], as a catalyst for

\footnotetext{
* Correspondence: gerald.guillaumet@univ-orleans.fr; lazar_said@yahoo.fr ${ }^{\dagger}$ Equal contributors

${ }^{2}$ Institut de Chimie Organique \& Analytique, UMR CNRS 7311, Université d'Orléans, BP 675945067, Orléans, Cedex 2, France

${ }^{1}$ Laboratoire de Biochimie, Environnement \& Agroalimentaire, URAC 36, Université Hassan II Mohammedia-Casablanca, Mohammedia, BP 14620650, Morocco

Full list of author information is available at the end of the article
}

crossed-aldol condensation [5], and as catalyst for synthesis of benzimidazoles, benzoxazoles, and benzothiazoles [6]. This new natural heterogeneous method led to $\beta$-sulfinyl adducts, $\alpha, \alpha^{\prime}$-bis(substituted benzylidene)cyclo-alkanones, benzimidazoles, benzoxazoles, and benzothiazoles in very high yields after only a few minutes at room temperature.

As an extension of our research program concerning the development of this natural catalyst, we report in this paper two successive ABM catalyzed reactions (Scheme $1)$. In order to determine the best catalytic system, recycling assays, modifications of several parameters such as temperature, thermal or microwave irradiation and choice of solvents were investigated.

The first novel ABM catalyzed reaction led to chalcones 3 which constitute an important class of biologically active compounds [7-12]. They are commonly synthesized by Claisen-Schmidt condensation between acetophenones $\mathbf{1}$
(C) Chemistry Central

C 2012 Riadi et al.; licensee Chemistry Central Ltd. This is an Open Access article distributed under the terms of the Creative Commons Attribution License (http://creativecommons.org/licenses/by/2.0), which permits unrestricted use, distribution, and reproduction in any medium, provided the original work is properly cited. 
and aromatic aldehydes 2 under acidic and basic homogeneous conditions or using basic heterogeneous catalysts.

Alumina [13], barium hydroxide [14-17], hydrotalcite [18], zeolite [19] natural phosphate either alone or activated with an ammonium salt [20] and hydroxyapatite derivatives [21-23] were previously used in heterogeneous reactions to facilitate separation and obtain pure products.

Scheme 1 (a) Claisen-Schmidt condensation catalyzed by $\mathrm{ABM}, \mathrm{KF} / \mathrm{ABM}$ or $\mathrm{NaNO}_{3} / \mathrm{ABM}$; (b) Aza-Michael addition by $A B M, K F / A B M$ or $\mathrm{NaNO}_{3} / \mathrm{ABM}$ catalyst.

The second new ABM catalyzed reaction we tried is the Michael addition of an aromatic amine 4 on a chalcone 3 for the synthesis of $\beta$-amino carbonyl compounds 5. Previously, similar reactions have been carried out with no special activation (limited cases) [23,24] but most of them required a Lewis acid [25-27] and other stronger reaction conditions $[28,29]$ to promote conjugation addition of amines to $\alpha, \beta$-unsaturated carbonyl compounds. Solvent-free reactions, heterogeneous solid acids, ionic liquids, and high temperature have also been used to promote this reaction [30].

Unfortunately, as shown previously, many of these Claisen-Schmidt and aza-Michael procedures often required an excess of reagents, long reaction times, and used expensive heavy metal salts and drastic reaction conditions. The development of a simpler, eco-friendly and efficient catalytic method for the Claisen-Schmidt and aza-Michael reactions is therefore highly desirable. $\mathrm{ABM}$ and doped $\mathrm{ABM}$ could offer a good alternative in this respect.

\section{Catalyst preparation - characterization}

ABM process preparation [31] offers the possibility to obtain a modified catalyst. KF/ABM and $\mathrm{NaNO}_{3} / \mathrm{ABM}$ doped bones were prepared by impregnating the natural product with an aqueous solution of potassium fluoride or sodium nitrate respectively. The mixture was stirred vigorously at room temperature, evaporated to dryness, dried and calcined at $800^{\circ} \mathrm{C}$ for $2 \mathrm{~h}$. to obtain two novel active catalysts.

In order to determine the best ratio $r=m_{0}$ (KF or $\left.\mathrm{NaNO}_{3}\right) / \mathrm{m}_{1}$ (ABM), we carried out the synthesis of chalcone 3 a by condensation of benzaldehyde and acetophenone at room temperature in the presence of methanol $(1 \mathrm{~mL})$ and $\mathrm{KF} / \mathrm{ABM}$ or $\mathrm{NaNO}_{3} / \mathrm{ABM}(50 \mathrm{mg})$ with weight ratios $\mathrm{r}=3 / 4,1 / 2,1 / 3,1 / 4,1 / 6,1 / 8,1 / 10,1 / 15$ and 0 (ABM alone) respectively. In the presence of $\mathrm{NaNO}_{3}$ or KF alone, no product was observed under the reaction conditions; only the starting material was isolated (Figure 1).

The conversion of the starting materials is maximal for a weight ratio $\mathrm{KF}$ or $\mathrm{NaNO}_{3} /$ bones $=1 / 2$. The new catalysts obtained under these conditions were characterized by X-ray diffraction (Figure 2).

We previously reported the elemental analysis of ABM which showed high levels of phosphate (56.3\%) and calcium $(36.8 \%)$, with a $\mathrm{Ca} / \mathrm{P}$ ratio of 1.55 . Only strong characteristic phosphate bands were observed in X-Ray spectra using doped ABMs. X-Ray diffraction analysis confirmed the presence of hydroxyapatite without solid material modifications.

The only remarkable fact is that the main modifications in the X-Ray diffraction patterns of KF/ABM and $\mathrm{NaNO}_{3} / \mathrm{ABM}$ are produced in the range of $2 \theta=32-35^{\circ}$, in this range we have new lines with an increase in the intensity of other lines in that zone. These lines may correspond to sodium or potassium phosphate species.

\section{Optimizations for abms catalyzed Claisen-Schmidt condensations}

Having thus demonstrated the ability to convert benzophenone and benzaldehyde into 3a using the three newly prepared ABMs, we next envisioned optimizing the process of the reaction.

The reaction was therefore carried out using an equimolar amount of benzaldehyde and acetophenone (1.0 mmol) in various quantities of methanol. In the absence of solvent the reaction failed. The addition of methanol enhanced the yield up to $1.5-2.5 \mathrm{~mL}$ which appeared to be the best volume for achieving complete conversion of the starting material and obtaining 3a in near quantitative yields. Efficient solvation of the reagents and contact optimizations between the active sites of the catalyst and the organic substrates could explain this result. Beyond $2 \mathrm{~mL}$ of $\mathrm{MeOH}$, the dispersion phenomenon leads to a decrease in yields.

Various chalcones 3 were then prepared by reacting arylaldehydes 1 on ketones 2 in the presence of methanol as the solvent and catalyst (i.e. ABM or KF or $\mathrm{NaNO}_{3}$ doped ABMs) at room temperature (Figure 3). Under similar conditions in the absence of the catalysts, only the starting material was recovered, thus highlighting the role of this catalyst. At the end of the reaction a solvent addition, filtration and evaporation were realized in order to easily quantify the yield all the products were characterized using standard ${ }^{1} \mathrm{H},{ }^{13} \mathrm{C}$ NMR and IR spectrometry after re-crystallization.

Using ABM alone, yields never exceeded 17\%. In each entry, $\mathrm{KF} / \mathrm{ABM}$ and $\mathrm{NaNO}_{3} / \mathrm{ABM}$ gave higher yields than using ABM alone (Table 1). With our new catalysts, the reaction worked efficiently at room temperature in good yields, affording chalcones $\mathbf{3}$ in high purity. In the case of the synthesis of chalcones $\mathbf{3 a}, \mathbf{3 1}-\mathbf{3 r}$, the kinetic reactions were slowed down and required more time. The presence of an electron-donor group on acetophenones 2m-2r $\left(-\mathrm{OCH}_{3}\right)$ decreased their reactivity towards benzaldehydes whereas an electron-acceptor 


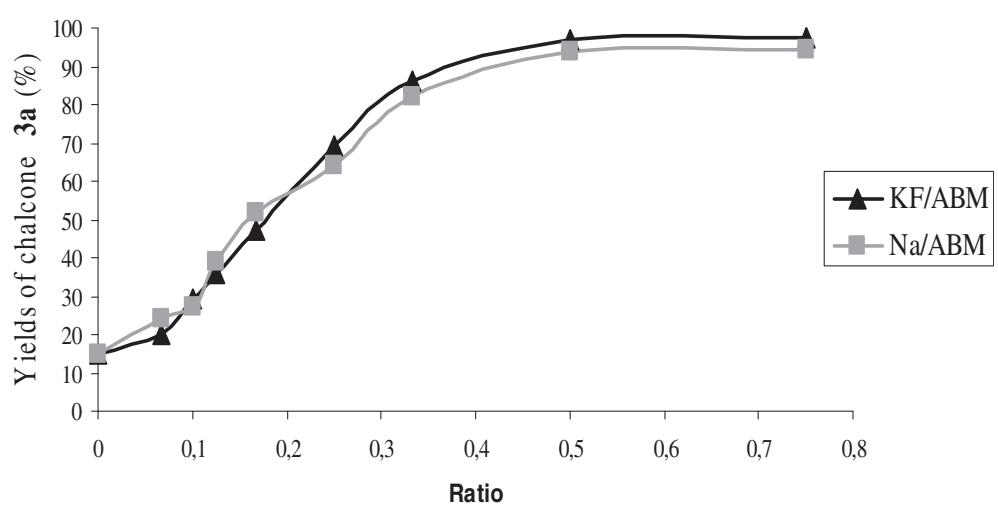

Figure 1 Yields of $3 a$ using $\mathrm{KF} / \mathrm{ABM}$ and $\mathrm{NaNO}_{3} / \mathrm{ABM}$ with different weight ratios.

group such as $-\mathrm{NO}_{2}$ increased the reactivity of the corresponding acetophenones (2g-2k) except in case $\mathbf{2} \mathbf{l}$.

In general, it appeared that KF/ABM and $\mathrm{NaNO}_{3} /$ $\mathrm{ABM}$ were more active than $\mathrm{ABM}$, and that the addition of $\mathrm{KF}$ or $\mathrm{NaNO}_{3}$ to $\mathrm{ABM}$ also increased the activity of the heterogeneous catalysts.

Recovering and re-using the solid catalyst is one of the major interests of heterogeneous catalysis. For this
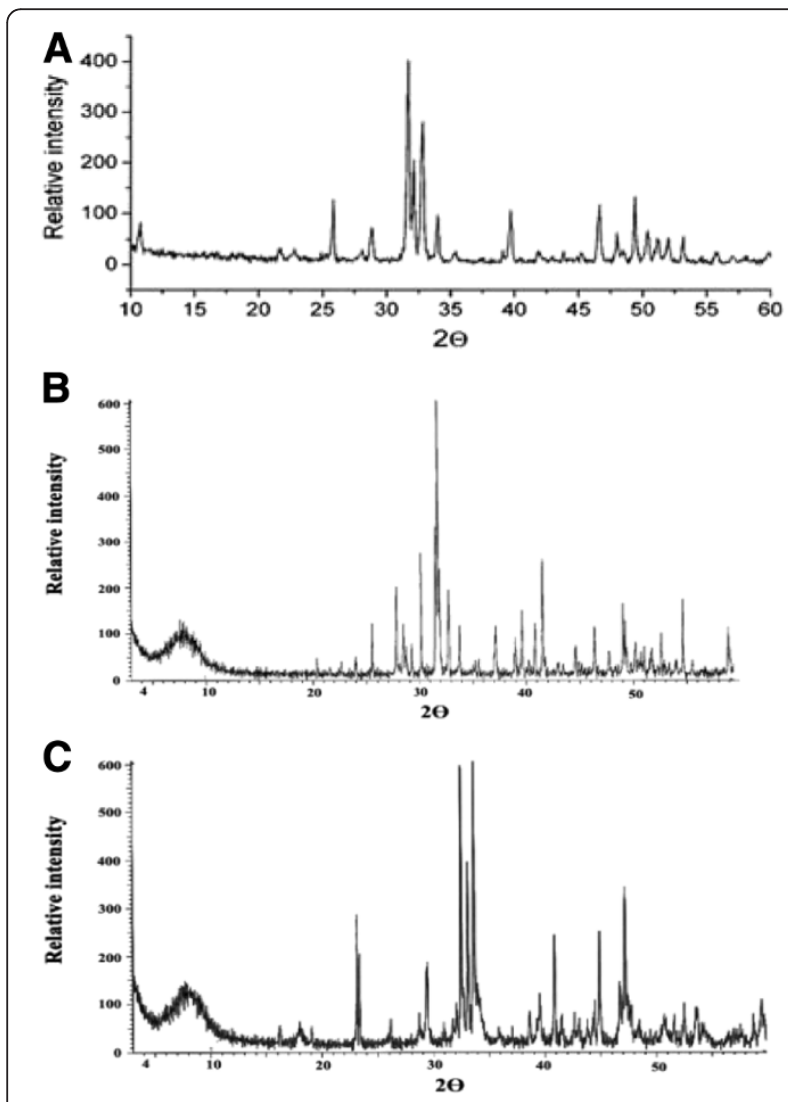

Figure 2 (A) X-Ray diffraction patterns of ABM (B) X-Ray diffraction patterns of KF/ABM and (C) X-Ray diffraction patterns of $\mathrm{NaNO}_{3} / \mathrm{ABM}$ at weight ratio $=0.5$. purpose, the synthesis of 3a was carried out using fresh and recovered catalyst $\mathrm{NaNO}_{3} / \mathrm{ABM}$. The $\mathrm{NaNO}_{3} / \mathrm{ABM}$ was quantitatively recovered by simple filtration and regenerated by calcination at $400^{\circ} \mathrm{C}$ for two hours for each new reuse (usage).

After the third recycling procedure, the yield of the reaction and the amount recovered $\mathrm{NaNO}_{3} / \mathrm{ABM}$ decreased slowly (Table 2). Nevertheless, the recycling procedure proved its efficiency and it should be noted that even in the fifth round of reuse of the catalyst the corresponding product 3a was obtained in fairly good yield.

Even if chalcone synthesis proved its efficiency at room temperature, we next sought to find other conditions including replacing the organic solvent with water. For this new objective, a mixture of aldehydes $\mathbf{1}$, acetophenones 2 (2.5 mmol) and doped ABMs was prepared in water and the suspension irradiated under microwave for the proper time at temperature $160^{\circ} \mathrm{C}$ and under pressure 10 bar. Simple purification led to the desired chalcones 3 (Table 3 ).

The reaction proceeded under microwave irradiation in good yields and high purity (Table 4). The reaction time was significantly reduced for each assay and products were obtained after only a few minutes. Electronic effects due to acetophenone and benzaldehyde substitutions persisted.

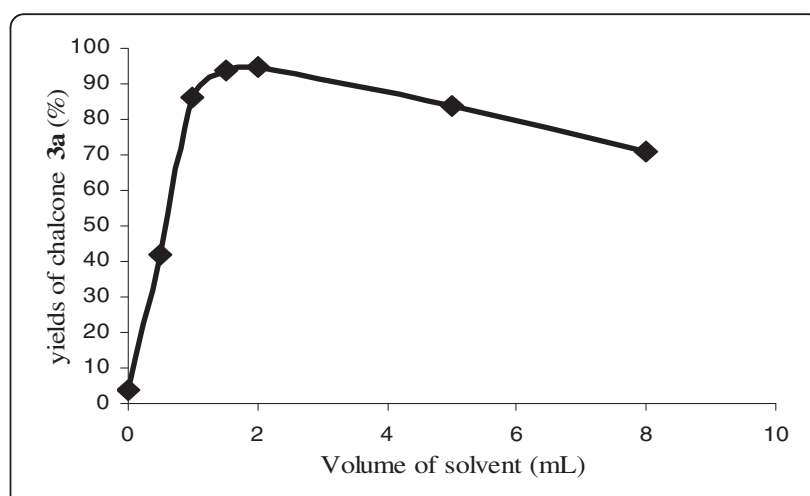

Figure 3 Volume of $\mathrm{MeOH}$ effect on chalcone 3a synthesis. 
Table 1 Synthesis of chalcones 3 in presence of ABM, KF/ ABM or $\mathrm{NaNO}_{3} / \mathrm{ABM}$ at room temperature in $\mathrm{MeOH}$

\begin{tabular}{|c|c|c|c|c|c|c|}
\hline \multirow[t]{2}{*}{ Entry } & \multicolumn{3}{|c|}{ Product } & \multicolumn{3}{|c|}{ Yields $^{\mathrm{a}}(\%) /$ Time $(\mathrm{h})$} \\
\hline & $\mathrm{N}^{\circ}$ [ref] & $x$ & $\mathrm{Y}$ & $A B M$ & $\mathrm{KF} / \mathrm{ABM}$ & $\mathrm{NaNO}_{3} / \mathrm{ABM}$ \\
\hline 1 & $\mathbf{3 a}[32]$ & $\mathrm{H}$ & $\mathrm{H}$ & $15 / 24$ & $97 / 12$ & $96 / 12$ \\
\hline 2 & $\mathbf{3 b}[33]$ & $\mathrm{NO}_{2}$ & $\mathrm{H}$ & $13 / 12$ & $93 / 6$ & $91 / 5$ \\
\hline 3 & $\mathbf{3 c}[32]$ & $\mathrm{OCH}_{3}$ & $\mathrm{H}$ & $5 / 12$ & $94 / 9$ & $91 / 6$ \\
\hline 4 & $\mathbf{3 d}[32]$ & $\mathrm{Cl}$ & $\mathrm{H}$ & $10 / 12$ & $90 / 6$ & $93 / 6$ \\
\hline 5 & $\mathbf{3 e}[33]$ & $\mathrm{CH}_{3}$ & $\mathrm{H}$ & $5 / 12$ & $91 / 9$ & $86 / 9$ \\
\hline 6 & $3 f[34]$ & $\mathrm{F}$ & $\mathrm{H}$ & $17 / 12$ & $90 / 6$ & $92 / 6$ \\
\hline 7 & $\mathbf{3 g}[35]$ & $\mathrm{H}$ & $\mathrm{NO}_{2}$ & $6 / 12$ & $97 / 6$ & $95 / 6$ \\
\hline 8 & $\mathbf{3 h}[32]$ & $\mathrm{OCH}_{3}$ & $\mathrm{NO}_{2}$ & $4 / 12$ & $94 / 6$ & $92 / 6$ \\
\hline 9 & $3 \mathbf{3}[35]$ & $\mathrm{Cl}$ & $\mathrm{NO}_{2}$ & $8 / 12$ & $93 / 6$ & $89 / 8$ \\
\hline 10 & $\mathbf{3 j}[36]$ & $\mathrm{NO}_{2}$ & $\mathrm{NO}_{2}$ & $11 / 12$ & $94 / 6$ & $97 / 6$ \\
\hline 11 & $\mathbf{3 k}[37]$ & $\mathrm{CH}_{3}$ & $\mathrm{NO}_{2}$ & $5 / 12$ & $96 / 9$ & $92 / 9$ \\
\hline 12 & $3 \mathbf{1}[38]$ & $\mathrm{F}$ & $\mathrm{NO}_{2}$ & $17 / 12$ & $90 / 16$ & $87 / 12$ \\
\hline 13 & $3 m[32]$ & $\mathrm{H}$ & $\mathrm{OCH}_{3}$ & $9 / 12$ & $85 / 12$ & $88 / 12$ \\
\hline 14 & $\mathbf{3 n}[39]$ & $\mathrm{NO}_{2}$ & $\mathrm{OCH}_{3}$ & $17 / 12$ & $88 / 12$ & $82 / 12$ \\
\hline 15 & $\mathbf{3 o}[32]$ & $\mathrm{Cl}$ & $\mathrm{OCH}_{3}$ & $2 / 12$ & $89 / 12$ & $91 / 12$ \\
\hline 16 & $\mathbf{3 p}[39]$ & $\mathrm{CH}_{3}$ & $\mathrm{OCH}_{3}$ & $6 / 12$ & $79 / 16$ & $87 / 16$ \\
\hline 17 & $\mathbf{3 q}[32]$ & $\mathrm{OCH}_{3}$ & $\mathrm{OCH}_{3}$ & $4 / 12$ & $86 / 16$ & 79/16 \\
\hline 18 & $3 \mathbf{r}[40]$ & $\mathrm{F}$ & $\mathrm{OCH}_{3}$ & $14 / 12$ & $92 / 12$ & $94 / 12$ \\
\hline
\end{tabular}

${ }^{\mathrm{a}}$ Yields refer to isolated compounds.

Compared the two methods the first reaction is performed at atmospheric pressure and the second one under pressure. In general, when the reaction was performed at atmospheric pressure the condensation has allowed the isolation of our products in good yields (Table 1). The reactions are relatively slow. The use of microwave decreases remarkably the reaction time and the attempted products were isolated in good yields after only few minutes (Table 2).

\section{Optimizations for ABMs catalyzed aza-Michael additions}

The next step was to use our ABM catalysts for aza-Michael addition using some of the previously synthesized chalcones with amines 4. For this new proposal, the catalyst (ABM, $\mathrm{KF} / \mathrm{ABM}$ or $\mathrm{NaNO}_{3} / \mathrm{ABM}, 100 \mathrm{mg}$ ) was added to an equimolar mixture of aniline, $p$-methoxyaniline or benzylamine

Table 2 Studies on the reuse of $\mathrm{NaNO}_{3} / \mathrm{ABM}$ in the synthesis of chalcone $3 a$

\begin{tabular}{lccc}
\hline Entry & Round & Yield (\%) & Recovered $\mathrm{NaNO}_{3} / \mathrm{ABM}(\%)$ \\
\hline 1 & 1 & 96 & 97 \\
2 & 2 & 96 & 96 \\
3 & 3 & 92 & 94 \\
4 & 4 & 89 & 89 \\
5 & 5 & 81 & 83 \\
\hline
\end{tabular}

Table 3 Synthesis of chalcones 3 in presence of KF/ABM or $\mathrm{NaNO}_{3} / \mathrm{ABM}$ under microwave irradiation

\begin{tabular}{|c|c|c|c|c|c|}
\hline \multirow[t]{2}{*}{ Entry } & \multicolumn{3}{|c|}{ Product } & \multicolumn{2}{|c|}{ Yields $^{\mathrm{a}}(\%) /$ Time $(\mathrm{min})$} \\
\hline & $\mathbf{N}^{\circ}$ & $x$ & $\mathrm{Y}$ & KF/ABM & $\mathrm{NaNO}_{3} / \mathrm{ABM}$ \\
\hline 1 & $3 a$ & $\mathrm{H}$ & $\mathrm{H}$ & $88 / 20$ & $83 / 20$ \\
\hline 2 & $3 b$ & $\mathrm{NO}_{2}$ & $\mathrm{H}$ & $82 / 20$ & $84 / 20$ \\
\hline 3 & $3 c$ & $\mathrm{OCH}_{3}$ & $\mathrm{H}$ & $82 / 30$ & $89 / 20$ \\
\hline 4 & $3 d$ & $\mathrm{Cl}$ & $\mathrm{H}$ & $93 / 20$ & $93 / 20$ \\
\hline 5 & $3 g$ & $\mathrm{H}$ & $\mathrm{NO}_{2}$ & $91 / 20$ & $96 / 20$ \\
\hline 6 & $3 h$ & $\mathrm{OCH}_{3}$ & $\mathrm{NO}_{2}$ & $85 / 20$ & $81 / 20$ \\
\hline 7 & $3 \mathbf{i}$ & $\mathrm{Cl}$ & $\mathrm{NO}_{2}$ & $94 / 20$ & $97 / 20$ \\
\hline 8 & $3 \mathbf{j}$ & $\mathrm{NO}_{2}$ & $\mathrm{NO}_{2}$ & $91 / 25$ & $93 / 20$ \\
\hline 9 & $3 m$ & $\mathrm{H}$ & $\mathrm{OCH}_{3}$ & $79 / 30$ & $82 / 20$ \\
\hline 10 & $3 n$ & $\mathrm{NO}_{2}$ & $\mathrm{OCH}_{3}$ & $84 / 30$ & $84 / 30$ \\
\hline 11 & 30 & $\mathrm{Cl}$ & $\mathrm{OCH}_{3}$ & $78 / 30$ & $86 / 30$ \\
\hline 12 & $3 q$ & $\mathrm{OCH}_{3}$ & $\mathrm{OCH}_{3}$ & $72 / 35$ & $83 / 35$ \\
\hline
\end{tabular}

${ }^{a}$ Yields refer to isolated compounds.

and chalcones (3a-d) in methanol. The mixture was stirred at room temperature until completion of the reaction (TLC). After filtration, the catalyst was washed with dichloromethane and after a simple purification step, the Michael adducts 5 were analyzed by ${ }^{1} \mathrm{H},{ }^{13} \mathrm{C}$ NMR and IR spectrometry. Reaction of 3a with aniline performed in $\mathrm{MeOH}$ without $\mathrm{ABM}$ was inefficient and the product $\mathbf{5} \mathbf{a}$ was not detected.

In the presence of $\mathrm{KF}$ or $\mathrm{NaNO}_{3}$ alone, no 1,4-addition occurred, whatever the reaction time tried. In general the use of $\mathrm{ABM}$ alone led to the Michael adducts $\mathbf{5}$ in good (entry 1) to moderate yields (entry 12) and

Table 4 Aza-Michael addition in presence of ABM, KF/ ABM or $\mathrm{NaNO}_{3} / \mathrm{ABM}$

\begin{tabular}{|c|c|c|c|c|c|c|}
\hline \multirow[t]{2}{*}{ Entry } & \multicolumn{3}{|c|}{ Product } & \multicolumn{3}{|c|}{ Yields $^{\mathrm{a}}(\%) /$ Time (h) } \\
\hline & $\mathrm{N}^{\circ}$ [ref] & $\mathbf{R}$ & $\mathrm{x}$ & ABM & KF/ABM & $\mathrm{NaNO}_{3} / \mathrm{ABM}$ \\
\hline 1 & $5 a[41]$ & $\mathrm{C}_{6} \mathrm{H}_{5}$ & $\mathrm{H}$ & $95 / 6$ & $96 / 0.5$ & $93 / 1$ \\
\hline 2 & $5 \mathbf{b}[42]$ & $\mathrm{C}_{6} \mathrm{H}_{5}$ & $\mathrm{NO}_{2}$ & $86 / 12$ & $93 / 1$ & $94 / 1$ \\
\hline 3 & $\mathbf{5 c}[41]$ & $\mathrm{C}_{6} \mathrm{H}_{5}$ & $\mathrm{OCH}_{3}$ & $75 / 12$ & $93 / 3$ & $91 / 3$ \\
\hline 4 & $\mathbf{5 d}[41]$ & $\mathrm{C}_{6} \mathrm{H}_{5}$ & $\mathrm{Cl}$ & $89 / 12$ & $90 / 1$ & $94 / 1$ \\
\hline 5 & $\mathbf{5 e}[43]$ & $p-\mathrm{CH}_{3} \mathrm{OC}_{6} \mathrm{H}_{4}$ & $\mathrm{H}$ & $86 / 12$ & $97 / 2$ & $94 / 1$ \\
\hline 6 & $\mathbf{5 f}[44]$ & $p-\mathrm{CH}_{3} \mathrm{OC}_{6} \mathrm{H}_{4}$ & $\mathrm{NO}_{2}$ & $74 / 12$ & $90 / 4$ & $93 / 4$ \\
\hline 7 & $\mathbf{5 g}[42]$ & $p-\mathrm{CH}_{3} \mathrm{OC}_{6} \mathrm{H}_{4}$ & $\mathrm{OCH}_{3}$ & $68 / 12$ & $94 / 3$ & $93 / 3$ \\
\hline 8 & $\mathbf{5 h}[45]$ & $p-\mathrm{CH}_{3} \mathrm{OC}_{6} \mathrm{H}_{4}$ & $\mathrm{Cl}$ & $78 / 12$ & $92 / 3$ & $91 / 2$ \\
\hline 9 & $5 i[44]$ & $\mathrm{C}_{6} \mathrm{H}_{5} \mathrm{CH}_{2}$ & $\mathrm{H}$ & $59 / 12$ & $95 / 12$ & $91 / 12$ \\
\hline 10 & $5 \mathbf{j}[46]$ & $\mathrm{C}_{6} \mathrm{H}_{5} \mathrm{CH}_{2}$ & $\mathrm{NO}_{2}$ & $67 / 12$ & $92 / 6$ & $93 / 6$ \\
\hline 11 & $5 \mathbf{k}[44]$ & $\mathrm{C}_{6} \mathrm{H}_{5} \mathrm{CH}_{2}$ & $\mathrm{OCH}_{3}$ & $62 / 12$ & $91 / 6$ & $89 / 6$ \\
\hline 12 & $5 \mathbf{I}[44]$ & $\mathrm{C}_{6} \mathrm{H}_{5} \mathrm{CH}_{2}$ & $\mathrm{Cl}$ & $48 / 12$ & $84 / 16$ & $81 / 16$ \\
\hline
\end{tabular}


completion was obtained only after $12 \mathrm{~h}$ (except for the reaction of 3a with aniline, $6 \mathrm{~h}$ ).

The use of ABM doped with $\mathrm{KF}$ or $\mathrm{NaNO}_{3}$ increased the catalytic activity remarkably. The very high yields (84-95\% for KF/ABM and $81-94 \%$ for $\mathrm{NaNO}_{3} / \mathrm{ABM}$ could be noted. The rapidity of the reaction $(0.5-4 \mathrm{~h})$ using aniline and $p$-methoxyaniline proved the efficiency of these new catalytic systems. The sole limitations observed concern the use of benzylamine. In this case, the yields are higher but the reaction time increases to $6 \mathrm{~h}$ (entries 10, 11 ) and up to $16 \mathrm{~h}$ starting from the chlorochalcone $\mathbf{3 d}$.

Reuse of the doped ABM was investigated and a cycle of five aza-Michael additions was conducted. Each reaction produced the corresponding product $\mathbf{5 a}$ in fairly good yield. KF/ABM was collected after each reaction and regenerated by calcination at $400^{\circ} \mathrm{C}$ for two hours for each new reuse (Table 5). During five cycles the catalyst was near quantitatively recovered but a slight decrease in yield was observed.

\section{Conclusions}

$\mathrm{ABM}$ and $\mathrm{KF}$ or $\mathrm{NaNO}_{3}$ doped ABMs are efficient catalysts for performing Claisen-Schmidt condensation and aza-Michael additions under mild conditions. $\mathrm{MeOH}$ at room temperature and water under microwave irradiation offer two synthetic alternatives. These promising catalysts are very attractive and can be reused several times after simple filtration and calcination.

$\mathrm{ABM}$ and its $\mathrm{KF}$ or $\mathrm{NaNO}_{3}$ doped analogs are inexpensive and attractive solid supports which can contribute to the development of catalytic processes and reduce environmental problems.

\section{Experimental}

General procedure for Claisen-Schmidt condensation: Chalcones 3 were prepared by reacting $(2.5 \mathrm{mmol})$ arylaldehydes 1 and $(2.5 \mathrm{mmol})$ ketones 2 in the presence of methanol $(6.5 \mathrm{~mL})$ as the solvent and $100 \mathrm{mg}$ catalyst $\mathrm{ABM}$ or $50 \mathrm{mg}$ of doped $\mathrm{ABM}$ at room temperature. $\mathrm{CH}_{2} \mathrm{Cl}_{2}(2 \times 20 \mathrm{~mL})$ was added, followed by simple filtration. The solution was concentrated and the crude material was purified by recrystallization.

General procedure for Claisen-Schmidt condensation under microwave irradiation: To a solution of aldehyde

Table 5 Studies on the reuse of KF/ABM in the synthesis of product 5a

\begin{tabular}{cccc}
\hline Entry & Round & Yield (\%) & Recovered KF/ABM (\%) \\
\hline 1 & 1 & 96 & 99 \\
2 & 2 & 92 & 96 \\
3 & 3 & 92 & 96 \\
4 & 4 & 89 & 90 \\
5 & 5 & 81 & 89 \\
\hline
\end{tabular}

$1(2.5 \mathrm{mmol})$ and acetophenone $2(2.5 \mathrm{mmol})$ in water $(300 \mu \mathrm{L})$ were added $100 \mathrm{mg}$ of catalyst and the mixture was stirred at room temperature for $5 \mathrm{~min}$. The mixture was irradiated by microwave for the appropriate time at $160^{\circ} \mathrm{C} . \mathrm{CH}_{2} \mathrm{Cl}_{2}(2 \times 20 \mathrm{~mL})$ was added, followed by simple filtration. The solution was concentrated and the crude material was purified by recrystallization.

General procedure for the aza-Michael additions: To a flask containing an equimolar mixture $(1.5 \mathrm{mmol})$ of amine 4 and chalcone derivative 3 in methanol $(1.5 \mathrm{~mL}), 100 \mathrm{mg}$ of catalyst (ABM, KF/ABM or $\mathrm{NaNO}_{3} / \mathrm{ABM}$ ) was added and the mixture was stirred at room temperature until completion of the reaction (TLC monitoring). The reaction mixture was filtered and the catalyst washed with dichloromethane. After concentration of the filtrate under reduced pressure the residue was subjected to chromatography ( $n$-hexane/EtOAc: $2 / 1$ ) or recrystallization leading to the Michael adduct 5 as a solid.

1,3-Bis-phenyl-propenone 3a: $\mathrm{mp} 59-60^{\circ} \mathrm{C}[33] ;{ }^{1} \mathrm{H}$ NMR $\left(\mathrm{CDCl}_{3}, 400 \mathrm{MHz}\right): \delta(\mathrm{ppm}) 8.12(2 \mathrm{H}, \mathrm{d}$, $J=8 \mathrm{~Hz}), 7.63(1 \mathrm{H}, \mathrm{d}, J=16 \mathrm{~Hz}), 7.45(1 \mathrm{H}, \mathrm{d}$, $J=16 \mathrm{~Hz}), 7.46-7.64(\mathrm{~m}, 6 \mathrm{H}), 7.32(2 \mathrm{H}, \mathrm{t}, J=8.8 \mathrm{~Hz})$ ppm; ${ }^{13} \mathrm{C}$ NMR $\left(\mathrm{CDCl}_{3}, 62.5 \mathrm{~Hz}\right): \delta$ (ppm) 191.01, $145.30,138.58,135.25,133.24,131.00,129.66,129.31$, 129.06, 128.93, 128.55, 122.44 .

1-(4-Nitrophenyl)-3-(4-Chlorophenyl)-propenone 3i: $\mathrm{mp} 171-172^{\circ} \mathrm{C}[36] ;{ }^{1} \mathrm{H}$ NMR $\left(\mathrm{CDCl}_{3}, 400 \mathrm{MHz}\right): \delta$ (ppm) $8.32(2 \mathrm{H}, \mathrm{d}, J=9.1 \mathrm{~Hz}), 8.11(2 \mathrm{H}, \mathrm{d}, J=8.8 \mathrm{~Hz})$, $7.74(1 \mathrm{H}, \mathrm{d}, J=15.8 \mathrm{~Hz}), 7.59(2 \mathrm{H}, \mathrm{d}, J=8.8 \mathrm{~Hz}), 7.42$ $(1 \mathrm{H}, \mathrm{d}, J=15.8 \mathrm{~Hz}), 7.36(2 \mathrm{H}, \mathrm{d}, J=8.8 \mathrm{~Hz}) ;{ }^{13} \mathrm{C}$ NMR $\left(\mathrm{CDCl}_{3}, 62.5 \mathrm{~Hz}\right): \delta(\mathrm{ppm})$ 187.96, 150.64, 148.97, 142.01, 133.79, 133.19, 130.12, 129.84, 124.29, 121.26.

1,3-Bis-(4-nitro-phenyl)-propenone $3 \mathbf{j}$ : $\mathrm{mp}$ 192$194^{\circ} \mathrm{C} ;{ }^{1} \mathrm{H}$ NMR $\left(\mathrm{CDCl}_{3}, 400 \mathrm{MHz}\right): \delta$ 8.06-7.81 (m, $8 \mathrm{H}), 7.79(\mathrm{~d}, 1 \mathrm{H}, J=16 \mathrm{~Hz}), 7.61(\mathrm{~d}, 1 \mathrm{H}, J=16 \mathrm{~Hz})$; ${ }^{13} \mathrm{C} \mathrm{NMR}\left(\mathrm{CDCl}_{3}, 62.5 \mathrm{~Hz}\right): \delta 189.7,142.0,139.2,137.6$, 133.3, 132.6, 128.8, 128.7, 128.5, 125.1, 113.5 .

1-(4-Nitrophenyl)-3-(4-fluorophenyl)-propenone 31: mp 178-179 ${ }^{\circ}$; ${ }^{1} \mathrm{H} \mathrm{NMR}\left(\mathrm{CDCl}_{3}, 400 \mathrm{MHz}\right): \delta 8.38$ (d, $2 \mathrm{H}, J=8 \mathrm{~Hz}), 8.31(\mathrm{~d}, 2 \mathrm{H}, J=8 \mathrm{~Hz}), 8.18(\mathrm{~d}, 2 \mathrm{H}$, $J=8 \mathrm{~Hz}), 7.88(\mathrm{~d}, 1 \mathrm{H}, J=16 \mathrm{~Hz}), 7.82(\mathrm{~d}, 2 \mathrm{H}, J=8 \mathrm{~Hz})$, $7.60(\mathrm{~d}, 1 \mathrm{H}, J=16 \mathrm{~Hz}) ;{ }^{13} \mathrm{C} \mathrm{NMR}\left(\mathrm{CDCl}_{3}, 62.5 \mathrm{~Hz}\right): \delta$ 188.7, 144.0, 140.7, 131.1, 129.6, 128.3, 120.7, 113.7.

1,3-Bis-(4-methoxyphenyl)-propenone 3q: mp 103$104^{\circ} \mathrm{C}$ [33]; ${ }^{1} \mathrm{H}$ NMR $\left(\mathrm{CDCl}_{3}, 400 \mathrm{MHz}\right): \delta$ (ppm) 8.01 $(\mathrm{d}, 2 \mathrm{H}), 7.77(\mathrm{~d}, 1 \mathrm{H}, J=7.6 \mathrm{~Hz}), 7.59(\mathrm{~d}, 2 \mathrm{H}$, $J=7.5 \mathrm{~Hz}), 7.41(\mathrm{~d}, 1 \mathrm{H}, J=15.5 \mathrm{~Hz}), 6.95(\mathrm{~d}, 2 \mathrm{H}$, $J=15.5 \mathrm{~Hz}), 6.90(\mathrm{~d}, 2 \mathrm{H}, J=7.5 \mathrm{~Hz}), 3.83(\mathrm{~s}, 3 \mathrm{H}), 3.80$ $(\mathrm{s}, 3 \mathrm{H}) .{ }^{13} \mathrm{C} \mathrm{NMR}\left(\mathrm{CDCl}_{3}, 62.5 \mathrm{~Hz}\right): \delta(\mathrm{ppm}) 189.3$, $164.4,161.4,143.9,132.3,131.6,131.1,128.7,114.5$, 113.3, 112.7, 55.7, 55.2.

1,3-Diphenyl-3-phenylamino-propan-1-one 5a: mp 170-171 ${ }^{\circ} \mathrm{C}[42] ;{ }^{1} \mathrm{H}$ NMR $\left(\mathrm{CDCl}_{3}, 400 \mathrm{MHz}\right): \delta$ (ppm) $7.92(\mathrm{~d}, 2 \mathrm{H}, J=8 \mathrm{~Hz}), 7.57(\mathrm{t}, 1 \mathrm{H}, J=8 \mathrm{~Hz}), 7.45(\mathrm{t}$, 
$2 \mathrm{H}, J=8 \mathrm{~Hz}), 7.25(\mathrm{t}, 1 \mathrm{H}, \mathrm{J}=8 \mathrm{~Hz}), 7.12-7.01(\mathrm{~m}, 5 \mathrm{H})$, 6.79-6.77 (m, $3 \mathrm{H}), 6.67(\mathrm{t}, 1 \mathrm{H}, J=8 \mathrm{~Hz}), 6.58(\mathrm{~d}, 2 \mathrm{H}$, $J=8 \mathrm{~Hz}$ ), 4.98 (dd, $1 \mathrm{H}, \mathrm{J}=8$; $5 \mathrm{~Hz}$ ); 4.55 (br s, $1 \mathrm{H}$ ); 3.51 (dd, $1 \mathrm{H}, J=16 ; 5 \mathrm{~Hz}) ; 3.43$ (dd, $1 \mathrm{H}, J=16 ; 8 \mathrm{~Hz}) ;{ }^{13} \mathrm{C}$ NMR $\left(\mathrm{CDCl}_{3}, 62.5 \mathrm{~Hz}\right): 198.96,197.80,146.20,136.48$, $135.00,133.61,129.52,128.79,128.63,128.18,118.76$, 114.00, 54.31, 40.92.

3-(4-Methoxy-phenylamino)-1,3-diphenyl-propan1-one 5e: $\mathrm{mp} 165-166^{\circ} \mathrm{C} \quad[45] ;{ }^{1} \mathrm{H}$ NMR $\left(\mathrm{CDCl}_{3}\right.$, $400 \mathrm{MHz}): \delta$ (ppm) 7.89 (d, $2 \mathrm{H}, J=8 \mathrm{~Hz}) ; 7.44(\mathrm{~d}, 2 \mathrm{H}$, $J=8 \mathrm{~Hz}) ; 7.32(\mathrm{t}, 2 \mathrm{H}, J=8 \mathrm{~Hz}) ; 7.24(\mathrm{t}, 1 \mathrm{H}, J=8 \mathrm{~Hz})$; $7.08(\mathrm{~d}, 2 \mathrm{H}, J=8 \mathrm{~Hz}) ; 6.65(\mathrm{t}, 1 \mathrm{H}, J=8 \mathrm{~Hz}) ; 6.55(\mathrm{~d}$, $2 \mathrm{H}, J=8 \mathrm{~Hz}$ ); 4.97 (dd, $1 \mathrm{H}, J=8 ; 4 \mathrm{~Hz}$ ); 4.61 (br s, $1 \mathrm{H}) ; 3.86$ (s, $3 \mathrm{H}) ; 3.45$ (dd, $1 \mathrm{H}, J=16 ; 4 \mathrm{~Hz}) ; 3.34$ (dd, $1 \mathrm{H}, J=16 ; 8 \mathrm{~Hz}) ;{ }^{13} \mathrm{C} \mathrm{NMR}\left(\mathrm{CDCl}_{3}, 62.5 \mathrm{~Hz}\right): \delta(\mathrm{ppm})$ $198.7,158.5,148.9,136.7,134.89,133.3,129.0,128.6$, 128.1, 117.7, 118.2, 114.4, 113.8, 55.2, 54.16, 46.3.

3-Benzylamino-3-(4-methoxy-phenyl)-1-phenylpropan-1-one 5k: mp $100-101^{\circ} \mathrm{C}[46] ;{ }^{1} \mathrm{H}$ NMR $\left(\mathrm{CDCl}_{3}\right.$, $400 \mathrm{MHz}): \delta(\mathrm{ppm}) 7.81(2 \mathrm{H}, J=8 \mathrm{~Hz}), 7.51-7.12$ (12 H, m), 4.5 (dd, $1 \mathrm{H}, J=8 \mathrm{~Hz}), 3.45-3.55$ (m, $2 \mathrm{H}), 3.2$ (dd, $2 \mathrm{H}, J=16 \mathrm{~Hz}), 3.3$ (s, $3 \mathrm{H}), 3.21(\mathrm{~s}, 1 \mathrm{H}) ;{ }^{13} \mathrm{C}$ NMR $\left(\mathrm{CDCl}_{3}, 62.5 \mathrm{~Hz}\right): 198.9,144.8,143.2,140.4,133.2,132.8$, $130.5,129.0,128.7,128.6,128.3,128.1,127.3,127.1$, $126.8,122.1,58.5,51.6,47.3,46.5$.

\section{Methods}

Instrumentation and materials. ${ }^{1} \mathrm{H}$ NMR and ${ }^{13} \mathrm{C}$ NMR were recorded on a Bruker Avance DPX250 spectrometer $\left(400 \mathrm{MHz}{ }^{1} \mathrm{H}, 62.89 \mathrm{MHz}{ }^{13} \mathrm{C}\right.$ ) using tetramethylsilane as the internal standard, multiplicities were determined by the DEPT 135 equivalence, chemical shifts were reported in parts per million (ppm, $\delta$ units). Coupling constants were reported in units of hertz $(\mathrm{Hz})$ if applicable.

Melting points were determined in open capillary tubes and are uncorrected. Flash chromatography was performed on silica gel 60 (40-63 mesh). Thin layer chromatography (TLC) was carried out on Merck silica gel $60 \mathrm{~F}_{254}$ precoated plates. Visualization was made with ultraviolet light. Chemicals products were obtained from the following sources: Aldrich and Acros organics.

Microwave (Biotage Initiator 2.5), Biotage microwave vials $2-5 \mathrm{~mL}$.

\section{Competing interests}

The authors declare that they have no competing interests.

\section{Authors' contributions}

YR, SL and GG participated in study design and coordination, manuscript preparation and carriedout he synthetic experiments, SR participated in study design and coordination and manuscript reparation. All authors read and approved the final manuscript.

\section{Acknowledgements}

Authors thank the "Volubilis" Hubert Curien Program for financial support.

\section{Author details}

${ }^{1}$ Laboratoire de Biochimie, Environnement \& Agroalimentaire, URAC 36, Université Hassan II Mohammedia-Casablanca, Mohammedia, BP 14620650, Morocco. ${ }^{2}$ Institut de Chimie Organique \& Analytique, UMR CNRS 7311, Université d'Orléans, BP 675945067, Orléans, Cedex 2, France. ${ }^{3}$ Laboratoire de Chimie Organique, Université Ibn Zohr, BP 810680000, Agadir, Morocco. ${ }^{4}$ Equipe de Chimie Analytique \& Environnement, Université Cadi Ayyad, BP 416246000, Safi, Morocco.

Received: 1 May 2012 Accepted: 11 June 2012

Published: 21 June 2012

\section{References}

1. Hattori H: Chem Rev 1995, 95:527.

2. Ono Y, Baba T: Catal Today 1997, 38:321.

3. Bennazha J, Zahouily M, Sebti S, Boukhari A, Holt EM: Catal Commun 2001, 2:101.

4. Riadi Y, Mamouni R, Abrouki Y, El Haddad M, Saffaj N, El Antri S, Routier S, Guillaumet G, Lazar S: Lett Org Chem 2010, 7:269.

5. Riadi Y, Mamouni R, Azzalou R, Boulahjar R, Abrouki Y, El Haddad M, Routier S, Guillaumet G, Lazar S: Tetrahedron Lett 2010, 51:6715.

6. Riadi Y, Mamouni R, Azzalou R, Routier S, Guillaumet G, Lazar S: Tetrahedron Lett 2011, 52:3492.

7. Dominguez JN, Charris JE, Lobo G, Gamboade Dominguez N, Moreno MM, Riggione F, Sanchez E, Olson J, Rosenthal PJ: Eur J Med Chem 2001, 36:555.

8. Chen M, Christensen SB, Kharazmi A: J Infect Dis 1997, 176:1327.

9. Hsieh HK, Tsao LT, Lin CN: J Pharm Pharmacol 2000, 52:163.

10. Herencia F, Ferrandiz ML, Alcaraz MJ: FEBS Lett 1999, 453:129.

11. Chen M, Zhai L, Christensen SB, Theander TG, Kharazmi A: Antimicrob Agents Chemother 2001, 45:2023.

12. DeVincenzo R, Ferlini C, Distefano M, Gaggini C, Riva A, Bombardelli E, Morazzoni P, Valenti P, Belluti F, Ranelletti FO: Cancer Chemother Pharmacol 2000, 46:305.

13. Varma RS, Kabalka GW, Evans LT, Pagni RM: Synth Commun 1985, 15:279.

14. Sinisterra JV, Garcia-Raso A, Cabello JA, Marinas JM: Synthesis 1984, 502.

15. Alcantara AR, Marinas JM, Siniseterra JV: Tetrahedron Lett 1987, 28:1515.

16. Aguilera A, Alcantara AR, Marinas JM, Sinisterra JV: Can J Chem 1987, 65:1165.

17. Sathyanarayana S, Krishnamurty HG: Curr Sci 1988, 57:1114.

18. Guida A, Lhouty MH, Tichit D, Figueras F, Geneste P: Appl. Catal. 1997, 164:251.

19. Climent MJ, Garcia H, Primo J, Corma A: Catal Lett 1990, 4:85.

20. Sebti S, Saber A, Rhihil A, Nazih R, Tahir R: Appl Catal A 2001, 206:217.

21. Mogilaiah K, Rao RB: Indian J Chem Sect B 1999, 38:869.

22. Ballini R, Bosica G, Maggi R, Ricciutelli M, Righi P, Sartori G, Sartorio R: Green Chem 2001, 3:178.

23. Pfau M: Bull Soc Chim Fr 1967, :117.

24. Ranu BC, Banerjee S: Tetrahedron Lett 2007, 48:141.

25. Cheng MS, Li RS, Kenyon G: Chin Chem Lett 2000, 11:851.

26. Wabnitz TC, Spencer JB: Tetrahedron Lett 2002, 43:3891.

27. Azizi N, Saidi MR: Tetrahedron 2004, 60:383.

28. Furukawa M, Okawara T, Terawaki Y: Chem Pharm Bull 1977, 25:1319. 29. Jenner G: Tetrahedron Lett 1995, 36:233.

30. Yang L, Xu LW, Zhou W, Li L, Xia CG: Tetrahedron Lett 2006, 47:7723.

31. Zahouily M, Bahlaouan B, Rayadh A, Sebti S: Tetrahedron Lett 2004, 45:4138.

32. Szell T, Sohar I: Can J Chem 1969, 47:1254.

33. Reddy GV, Maitraie D, Narsaiah B, Rambabu Y, Rao SP: Synth Comm 2001, $18: 2881$.

34. Kanagarajan V, Thanusu J, Gopalakrishnan M: Eur J Med Chem 2010, 45:1583.

35. Chtourou M, Abdelhédi R, Frikha MH, Trabelsi M: Ultrason Sonochem 2010, 17:246.

36. Wei W, Qunrong W, Liqin D, Aiqing Z, Duoyuan W: Ultrason Sonochem 2005, $12: 411$.

37. Mirjalili BF, Bamoniri A, Zarchi Karimi MA, Emtiazi H: J Iran Chem Soc 2010, 7:95.

38. Yulin Z, Yuanjiang P: Chem Lett 2004, 33:668.

39. Montes-Avila J, Díaz-Camacho SP, Sicairos-Félix J, Delgado-Vargas F, Rivero IA: Bioorg Med Chem 2009, 17:6780.

40. Mariappan G, Chandra DB, Buyan NR, Priya M: J Asian J Chem 2009, 21:6827.

41. Lu GP, Cai C: Catal Commun 2010, 11:745.

42. Dai Y, Li BD, Quan HD, Lu CX: Chin Chem Lett 2010, 21:31. 
43. Zahouily M, Mounir B, Charki H, Mezdar A, Bahlaouan B, Ouammou M: ARKIVOC 2006, 178

44. Kozlov NG, Basalaeva Ll: Russ J Gen Chem 2004, 74:926.

45. Dong F, Zhenghao F, Zuliang L: Catal Commun 2009, 10:1267.

46. Zahouily M, Charki H, Abrouki Y, Mounir B, Bahlaouan B, Rayadh A, Sebti S: Lett Org Chem 2005, 2:354.

doi:10.1186/1752-153X-6-60

Cite this article as: Riadi et al: New eco-friendly animal bone meal catalysts for preparation of chalcones and aza-Michael adducts.

Chemistry Central Journal 2012 6:60.

\section{Publish with ChemistryCentral and every scientist can read your work free of charge}

"Open access provides opportunities to our colleagues in other parts of the globe, by allowing anyone to view the content free of charge."

W. Jeffery Hurst, The Hershey Company.

- available free of charge to the entire scientific community

- peer reviewed and published immediately upon acceptance

- cited in PubMed and archived on PubMed Central

- yours - you keep the copyright

Submit your manuscript here:

Submit your manuscript here:
http://www.chemistrycentral.com/manuscript/<smiles>[c]1ccccc1</smiles> 